\title{
Collaborative and Co-curricular: Programming and Academic Library Impact
}

\author{
Katy Kelly
}

This study investigates how co-curricular programming in universities can demonstrate and communicate impact in new ways. The Association of College and Research Libraries report Academic Library Impact: Improving Practice and Essential Areas to Research provides a framework to better understand how co-curricular programming facilitates the following: aligning assessment with an institution's mission; enhancing teaching and learning; and communicating contributions. This article describes a model that other libraries may find useful as they plan and communicate their cocurricular programs to support the mission, vision, and strategic plan of their libraries and their institutions.

\section{Introduction}

Cohesive outreach strategies are in growing demand on campuses to support student success. Academic libraries use programming, a specific form of outreach, to address a variety of institutional goals. This study investigates how current and developing practices of cocurricular programming can demonstrate and communicate impact to stakeholders in new ways. Within this study, co-curricular programming is defined as a program or series of programs developed proactively by libraries to complement student learning, activities, or interests outside a for-credit class. The Association of College and Research Libraries (ACRL) report Academic Library Impact: Improving Practice and Essential Areas to Research ${ }^{1}$ describes priority areas for research on demonstrating and communicating impact. This study explores several of these priority areas as a framework to better understand how programming facilitates matching assessment to an institution's mission; enhancing teaching and learning; and communicating contributions.

In this study, the report and findings from a survey provide direction for libraries to effectively plan and communicate co-curricular programs to support the mission, vision, and strategies of their libraries and their institutions. Co-curricular programming offers flexibility to directly speak to campus initiatives and learning goals. It also fosters collaboration within the library, campus, and community. Acknowledging the changing landscape of academic libraries and barriers to co-curricular programming, this study also offers recommendations for implementing these programs.

\footnotetext{
* Katy Kelly is Coordinator of Marketing and Engagement/Associate Professor, University of Dayton Libraries; email:kkelly2@udayton.edu. (02020 Katy Kelly, Attribution-NonCommercial (https://creativecommons.org/licenses/ by-nc/4.0/) CC BY-NC.
} 


\section{Literature Review}

This study seeks to fill a gap within the literature about academic libraries' co-curricular programming and communicating results in support of institutional missions. In 2017, ACRL's report Academic Library Impact: Improving Practice and Essential Areas to Research ${ }^{2}$ reviewed and recommended actions and research questions for the study of these topics. The literature review will focus on planning programs, communicating value along the lines of institutional mission and goals, and the most recent efforts to urge libraries to connect these dots to demonstrate impact of programs.

\section{Planning Programs}

Co-curricular programming can enhance student learning, and libraries can shape their own strategies as they collaborate with other university or community partners. Program planning case studies describe effective campus collaborations for student programming in general, such as partnering with nonacademic departments to reach new students with programming; ${ }^{3}$ identifying short-term project-based collaborations like events with university divisions, including student government, ${ }^{4}$ and moving beyond collaboration and reacting to needs, into partnerships and a proactive role. ${ }^{5}$ Mary $\mathrm{O}^{\prime}$ Kelly describes how faculty may drive library use, but libraries can serve in co-curricular roles that support students' academic and social pursuits. ${ }^{6}$ Related to experiences in the physical library, many librarians label the library as sociologist Ray Oldenburg's concept of third place: It's neither home nor workplace but is comfortable to provide a sense of belonging and support for engagement and is marked by a playful mood. ${ }^{7}$ Programming can showcase the library as an "intellectual nexus" of campus, ${ }^{8}$ and the internet concept of sticky experiences (keeping people engaged on a website) can be applied to experiences, such as programming, in a library's physical setting. ${ }^{9}$ Events, exhibits, and programs can be planned and leveraged in ways that introduce new audiences to the library and encourage them to stay engaged with the library.

Rosan Mitola describes how co-curricular programming and learning experiences are recognized as a priority in the University of Nevada, Las Vegas (UNLV) Libraries' strategic plan as a way to support "academic achievement, life skills, and lifelong learning."10 Mitola describes UNLV Libraries' "plan, prioritize, partner model," which includes conducting a needs assessment and gathering feedback from library employees and current students to identify groups of students who would benefit from library outreach. ${ }^{11} \mathrm{UNLV}$ Libraries offers an excellent implementation model for aligning programs to a strategic plan and collaborating with partners.

Many existing studies call into question whether libraries intentionally develop outcomesbased, mission-centric programs and appropriate assessment and communication methods. Shannon L. Farrell and Kristen Mastel developed assessment techniques to fit common scenarios and program models in academic libraries. ${ }^{12} \mathrm{In}$ it, the authors state that "outreach is most effective when tied to institutional goals," which leads into a helpful literature review that describes the outreach landscape, six categories of outreach that they developed, and sample assessment strategies.

\section{Communicating Value}

Libraries see outreach as an opportunity to showcase their contributions to an institution. Collaboration and communication are essential to "market and link [library] service offer- 
ings to the institutional mission and goals in a way that is visible to provosts and other key stakeholders."13 Reporting and communication are both highly contextual, depending on the institution and the relationships or hierarchy within. Several strategies to accomplish this appear in the Value of Academic Libraries report. ${ }^{14}$ Aligning programs with larger goals is only one aspect; communicating about it opens up even more opportunities:

Academic librarians must understand institutional missions and how they contribute to them; they must also share that information with others by clearly aligning library services and resources to institutional missions. Communicating that alignment is crucial for communicating library value in institutional terms. ${ }^{15}$

Existing literature has multiple case studies about communicating the library's connections to institutional goals. Bonnie Lafazan and Jessica Kiebler discuss the importance and often-forgotten aspects of postpromotion and encourage libraries to use photography and video from the event and to share a report and assessment data with stakeholders "to demonstrate that the library is meeting its strategic goals." ${ }^{16}$ Assessment planning and its resulting data lead to the opportunity to communicate what happened and why it's important. O'Kelly includes "Who needs to see the results and why?" as two of seven questions to answer while crafting an effective assessment plan or simply to start a discussion. ${ }^{17}$ These questions can assist internally with planning; Dianne $\mathrm{Cmor}$ discusses approaching programming and services in a sustainable way and provides a template of what's externally shared to keep projects focused and manageable: "(1) objectives of the service/event/resource/tool under examination; (2) what was offered to our users; and (3) impact of the service/event/resource/tool."18 Sarah McNicol discusses ways that strategic plan priorities and results are communicated to campus actively, such as in formal committee settings, or passively, such as through annual reports. ${ }^{19}$ Kaitlin Springmier, Elizabeth Edwards, and Michelle B. Bass provide a benchmark on how academic libraries communicate their assessment projects publicly and found that libraries are using not just numbers, but also narratives and stories to provide context for the quantitative data collected.$^{20}$ Their study included libraries that used their strategic plans to provide a framework for their activities and goals.

\section{Impact of Programs}

Recent national initiatives include large-scale studies on programming. The American Library Association's National Impact of Library Public Programs Assessment (NILPPA) is researching the current landscape of public programming. A 2014 white paper found indications that programming has taken on more significance in recent years for all types of libraries. ${ }^{21}$ NILPPA's 2019 white paper, published after this research project, includes a finalized definition of public program: "A public program is a service or event in a group setting developed to meet the needs or interests of an anticipated target audience. All libraries, regardless of type, have a public - the audiences the library tailors its programs to and the people the library serves." ${ }^{22}$ Community knowledge is connected to figuring out the needs and wants within that community; NILPPA has identified challenges in this area and recommended how to move forward with a community needs assessment. Academic library workers can use NILPPA findings to do skills inventories for programming and build upon training resources for future planning. 
In a 2018 survey report, Association of Research Libraries (ARL) members show a wide variety of ways in which they connect their outreach activities, including goals and outcomes, with their own strategic plan, mission, or vision: "A full $96 \%$ of respondents reported aligning with initiatives such as diversity and inclusion, student retention, and community engagement." ${ }^{23}$ Survey results showed that libraries are doing outreach, even in the absence of its explicit inclusion in their mission or vision statements. In this study, however, outreach was defined by respondents, not the researchers, and included high participation in "tours ( $98 \%$ ), orientations (95\%), open houses (96\%), and resource tables (96\%)," and even social media $(95 \%) .{ }^{24}$ In comparison, this article focuses on a specific form of outreach-co-curricular programming for students-by asking program planners how they use strategic documents as a source of inspiration and guidance.

\section{Methods}

To compare and learn more about other academic libraries' co-curricular programming, the researcher devised a qualitative environmental scan and an online survey with the following research questions:

- Are our peer and aspirational peer academic libraries using their own and their school's mission, vision, strategic plan, and learning goals to plan co-curricular programs? If so, how?

- And, are programming results or outcomes reported to library and higher administration? If so, how?

The researcher identified a preliminary list of 66 peers. The Carnegie Size and Setting classification, which describes institutions' student population size and residential character, ${ }^{25}$ identified 38 peers, and University of Dayton's list of 21 peer institutions provided the rest. The literature review also helped identify seven aspirational peers. ACRL's Academic Library Impact report, the literature review, and information collected about peer libraries' events (accessible online) informed the survey questions. To focus on this particular form of outreach, the survey provided a definition of co-curricular programming influenced by NILPPA's own: "programs and series of programs developed proactively by libraries to complement student learning, activities, or interests." Practices and strategies were of particular interest, without excluding any type of program.

Reviewing each library's website and Facebook page determined whether or not a library was hosting or organizing programs. From the initial list, 59 out of 66 institutions (89\%) were promoting events through their library websites, Facebook posts, or Facebook events; 9 percent had no online evidence of programming, so those institutions were removed from the sample because the survey would be irrelevant to them. Out of the 66 institutions in the sample, 64 had Facebook pages (97\%). Though 17 out of 66 (26\%) had no evidence of programming on their website, 11 out of those 17 had evidence on their Facebook pages. Library websites do not tell the whole story; if library websites had been the only medium consulted, the researcher would not have discovered some programming examples and institutions that are active with programming. The review of websites also revealed examples of libraries using Springshare products such as LibCal to facilitate marketing and registration on their websites.

Following IRB approval, the 18-item online survey (see appendix) launched in March 2019 to investigate how academic libraries plan and report programs in support of their institutions' missions, strategic plans, and learning goals. To invite participation in the survey from employees knowledgeable of their libraries' programming activities, the researcher first attempted to 
identify an employee in an outreach, communication, or programming role on each library's staff directory. If there was no such position, the researcher contacted an employee in public services or administration. A $\$ 10$ credit to Amazon.com was offered as an incentive to participate. The researcher extended invitations to designated individuals at 59 peer and aspirational peer institutions to take the survey; all were known to be actively programming from the literature review and library websites. After an initial invitation and a follow-up, 12 people responded, each representing one peer or aspirational peer institution. The researcher coded and analyzed responses and found themes related to the following aspects: matching assessment to an institution's mission; enhancing teaching and learning; and communicating contributions.

\section{Results and Discussion}

The background research and literature review revealed popular program models, communication tools, and planning methods. Survey respondents answered multiple-choice and open-ended questions related to programming practices. They work in a variety of roles; the majority of respondents selected multiple job areas, as indicated in table 1 . The researcher developed a list of job roles that was representative of the invitees' job titles or departments.

Question 1 of the survey asked participants to select the types of programs their library offers or is currently planning. Categories for this question were adapted with permission from Shannon, L. Farrell and Kristen Mastel's study. ${ }^{26}$ The majority of respondents indicated that their libraries offer or were currently planning to offer more than four types of programs. Each category was selected by a minimum of two libraries, and a maximum of 11.

\begin{tabular}{|l|c|}
\hline \multicolumn{2}{|c|}{ Job Areas of Respondents } \\
\hline Job Areas & $\begin{array}{c}\text { Number of } \\
\text { Respondents }\end{array}$ \\
\hline Communication/Marketing; Reference/Instruction & 2 \\
\hline Library Administration; Communication/Marketing; Programming/Events/Exhibits & 3 \\
\hline Library Administration & 1 \\
\hline Library Administration; Communication/Marketing; Programming/Events/Exhibits; & 2 \\
\hline Reference/Instruction & \\
\hline Library Administration; Reference/Instruction; Archives/Special Collections & 1 \\
\hline Communication/Marketing & 1 \\
\hline Programming/Events/Exhibits; Reference/Instruction & 1 \\
\hline Programming/Events/Exhibits; Reference/Instruction; Archives/Special Collections & 1 \\
\hline Total & 12 \\
\hline
\end{tabular}

The following analysis incorporates select qualitative responses and is organized in relation to the Academic Library Impact report's priority areas: how programming facilitates matching assessment to an institution's mission; enhancing teaching and learning; and communicating contributions. Sections on practices and trends, barriers, and future directions provide insight for other libraries. Finally, this section includes recommendations for planning and reporting, as well as how this research may inform the programming activities at the author's institution. 


\begin{tabular}{|l|c|}
\hline \multicolumn{1}{|c|}{\begin{tabular}{c} 
Types of Programs \\
\hline
\end{tabular}} & $\begin{array}{c}\text { Number of } \\
\text { Libraries Offering } \\
\text { or Currently } \\
\text { Planning }\end{array}$ \\
\hline Type of Program & 11 \\
\hline $\begin{array}{l}\text { Programs that are designed around your library's collection. Examples may include } \\
\text { book clubs, common read events, or exhibits highlighting special collections or archives. }\end{array}$ & 10 \\
\hline $\begin{array}{l}\text { Co-curricular events that feature presentations or activities on your library's services } \\
\text { such as data management or specialized research using databases. }\end{array}$ & 3 \\
\hline $\begin{array}{l}\text { Programs that are designed to help students make personal progress in some } \\
\text { aspect of their life, including health-based programs. }\end{array}$ & 9 \\
\hline $\begin{array}{l}\text { Programs such as arts and crafts, concerts, puzzles, or games that may positively } \\
\text { influence the library environment. }\end{array}$ & \\
\hline $\begin{array}{l}\text { Programs that cross-promote your library's service with other campus units, } \\
\text { showcasing library collections/services at campus or community events outside the } \\
\text { library, or providing library space for programs led by groups, organizations, or clubs. }\end{array}$ & \\
\hline $\begin{array}{l}\text { Programs that take place over several days with multiple events and can be } \\
\text { a combination of the above categories. May be affiliated with new student } \\
\text { orientation, Banned Books Week, Open Access Week, or National Library Week. }\end{array}$ & 9 \\
\hline
\end{tabular}

\section{Programming and Mission Alignment}

ACRL's Academic Library Impact report lists a suggested action under the area of matching library assessment to institution's mission: "support student success by aligning services, collections, and spaces to support institutional objectives." ${ }^{27}$ This study examined how libraries' co-curricular programs, which could be considered a library service, connect to priority areas. Survey questions investigated alignment between co-curricular programs and the library's objectives, and also with the institution's objectives. Each respondent reported

TABLE 4

Frequency of Libraries Using Their Institution's Mission or Learning Goals to Guide Its Development of Co-Curricular Programs

\begin{tabular}{|l|c|c|}
\hline Answer & $\%$ & Count \\
\hline Always & $16.7 \%$ & 2 \\
\hline Very Often & $41.7 \%$ & 5 \\
\hline Sometimes & $8.3 \%$ & 1 \\
\hline Rarely & $33.3 \%$ & 4 \\
\hline Never & $0 \%$ & 0 \\
\hline Total & $100 \%$ & 12 \\
\hline
\end{tabular}
using their library's and institution's strategic plan, mission, or vision to guide their programming to some
TABLE 3

Frequency of Libraries Using Their Own Strategic Plan, Mission, and/or Vision to Guide Its Development of Co-Curricular Programs

\begin{tabular}{|l|c|c|}
\hline Answer & \% & Count \\
\hline Always & $33.3 \%$ & 4 \\
\hline Very often & $16.7 \%$ & 2 \\
\hline Sometimes & $33.3 \%$ & 4 \\
\hline Rarely & $16.7 \%$ & 2 \\
\hline Never & 0 & 0 \\
\hline Total & $100 \%$ & 12 \\
\hline
\end{tabular}
degree (see table 3).

Connecting programs to strategy, mission, and vision at the institutional level was a rarer occurrence than it is at the library level (see table 4). However, respondents' examples and ideas showed how intentionally using the same terminology and themes within programs can position the library as a strategic partner within the broader landscape of their institutions' programs and resources. One respondent stated, "Programming themes speak directly to the language that administration is looking at. This includes diversity and inclusion." Survey respondents and the background research 
showed a commitment to diversity-related topics within library programming, citing goals such as, "Students are aware of diverse ideas and cultures." One respondent offered, "The focus on 'transformative' undergraduate education pushes us to build programming and exhibits that showcase a variety of perspectives."

Another respondent described changing a library's programming focus to better fit conversations occurring:

New this year to our institution are two learning goals: graduate education and internationalization. These two aspects of the institutional strategic plan have encouraged us to develop new programs for these two groups of students. Our programs have included exhibitions about international campus life and workshops customized for graduate students.

Other themes directly related to positioning the library as a leader on campus regarding student success include "the value of information and scholarship as conversation," "affordable education/access," "inquiry and critical thinking or global/multicultural knowledge and awareness," and "experiential learning." These themes are also examples of ways in which programming can enhance subjective learning goals.

Respondents' examples showed how programs that intentionally align with campus priorities position libraries well within the broader landscape of their institutions' programs and resources. This alignment also informed how and why libraries measure the success of each program. From the data collected, one can reliably conclude that the respondent libraries' co-curricular programming is aligning with institutional learning goals and mission statements.

\section{Enhancing Teaching and Learning}

This section within ACRL's Academic Library Impact report describes how learning activities include opportunities beyond teaching. ${ }^{28}$ Collaborating with faculty, students, academic support areas, and campus partners can develop new opportunities, such as co-curricular programming, to foster leadership and partnerships toward shared learning goals.

Question 8 asked participants to select sources of inspiration for their co-curricular program themes or topics from a list developed from the literature review and website research. All options were selected at least once (see table 5).

Results from the survey indicated that expertise and interest from faculty members or campus partners inspired program development at these libraries. Surprisingly, looking to other institutions like public libraries and other academic libraries was less common. Results showed that the majority of respondents used local and unique sources of inspiration, such as academic courses and programs, archives and special collections, and the expertise of faculty, students, and library staff.

Programming lends itself well to committee participation and creative collaboration with campus partners. This collaboration naturally helps to showcase library expertise and resources. One respondent listed positive factors in program development: "Collaboration with other university groups, especially student groups if they are the target audience; good promotion; thoughtful content related to the library." Survey results showed co-curricular programming as a vehicle to demonstrating value and building relationships. 


\begin{tabular}{|l|c|c|}
\hline \multicolumn{2}{|c|}{ TABLE 5 } \\
\hline \multicolumn{2}{|c|}{ Sources of Inspiration for Co-curricular Program Themes or Topics } \\
\hline Source of Inspiration & Number of Libraries & $\%$ \\
\hline Academic Course(s) or Program(s) & 9 & $75 \%$ \\
\hline ACRL Framework for Information Literacy & 5 & $41.7 \%$ \\
\hline Campus Partners' Expertise or Interest & 11 & $91.7 \%$ \\
\hline Community Partners' Expertise or Interest & 8 & $66.7 \%$ \\
\hline Current Events (Local, National, International) & 8 & $66.7 \%$ \\
\hline The Institution's Special Collections or Archives & 10 & $83.3 \%$ \\
\hline The Institution's Arts Programming & 4 & $33.3 \%$ \\
\hline The Institution's Research Focus Areas & 5 & $41.7 \%$ \\
\hline Faculty Expertise or Interest & 11 & $91.7 \%$ \\
\hline Library Employee Expertise or Interest & 9 & $75 \%$ \\
\hline Local History & 8 & $66.7 \%$ \\
\hline National Themed Months or Weeks & 8 & $66.7 \%$ \\
\hline Other Institutions, including Academic Libraries & 2 & $16.7 \%$ \\
\hline Public Library Programs & 1 & $8.3 \%$ \\
\hline Student Expertise or Interest & 7 & $58.3 \%$ \\
\hline
\end{tabular}

Creating and maintaining relationships with campus groups, proactive faculty, and external unit partners has been key to program success. Examples of external partners included various academic success and resource centers and housing and residential life. Multiple respondents stated they are less likely to plan a program without a partner, such as a faculty member, campus group, or academic department. One respondent reported, "Our greatest success has been with true co-curricular planning and buy-in from faculty and campus partners." Programming provides a vehicle for libraries to identify effective and meaningful ways the library can be involved in teaching and learning.

The collaborative and interdisciplinary nature of programming allows many different planning partners to participate, including internal to the library and externally on campus. Respondents shared that programming tends to come from certain departments and committees, but the creation is open to all: "Any department in the library may develop a task related to this theme, although they tend to originate from the Administration Office or Teaching, Research \& Engagement unit," said one respondent. Another said, "Many people within the library are able to plan events, and as an organization, we are very open to campus and community partnerships." These responses show the equitable nature of programming - that all library workers can support student engagement, a call to action of enhancing teaching and learning. The openness of planning allows room for library workers to express their creativity, perspectives, and expertise while contributing to an institution's mission.

Survey participants recognized how programming enhances their libraries' abilities to connect to larger goals. However, programmers and marketers are often doing this work on top of existing time-sensitive and scheduled duties such as administration, archives, cataloging, reference, and instruction, which illustrates the perennial and often elusive endeavor in libraries to find balance as well as inspiration. Planners continually seek new ways to design inclusive, consistent, unified programming aligned with strategic priorities and their institutional missions. 


\section{Communicating Contributions}

Communication is essential to effective outreach at all stages and is a major theme in ACRL's Academic Library Impact report. Describing value can work effectively if libraries have a story to tell beyond merely numbers; co-curricular programming gives a context for these types of stories to flourish. All respondents (100\%) said they report programming results or outcomes to library administration. Two peers cited using Springshare LibInsight forms to capture quantitative data such as attendance counts. Respondents also talked about sharing qualitative data such as post-event survey responses and event observations. Some offered their available reporting channels, such as email, written reports, and verbal. Reporting doesn't always take the shape of a written report. One respondent offered, "I like to have debriefing meetings following programs to discuss what went well and what can be improved next time." In terms of timing, a few respondents produce a post-event report, while the majority create or contribute to an annual report for library administration. From this data emerged a potential best practice: a balance between obliging existing and accepted communication channels while still being able to discuss and act upon needed improvements.

Reporting to higher-level university administration was inconsistent, and reporting mechanisms were often unclear. Half of respondents (50\%) said they were aware of regular communication and reporting to university administration or external departments, typically in a library dean's or director's meeting with a provost. The majority stated this happens in an annual report, either written or verbal. One survey respondent provided a link to an annual report, accessible from an institutional repository, as an example. These findings relate to the ACRL report and its discussion of communication as being highly contextual.

\section{Barriers}

Like many library activities, co-curricular programming has its barriers. Comparisons between libraries can be helpful, to an extent. Libraries often look to peer institutions or beyond for inspiration and best practices. However similar libraries may be, comparisons are, in practice, of limited help. Every library has a different culture around the plethora of library services and trends. Unsuccessful attempts at programming can discourage libraries from trying again: "Previous low attendance has created a culture in which my colleagues do not want to do programming, which is one reason our programming is nearly non-existent. I am working to change this," said one respondent. Staffing models vary, and sometimes it's difficult to discern what is driving initiatives. "Time and staffing" were repeatedly cited as the major barriers to developing programming. One respondent cited responsibilities beyond programming as obstacles: "liaison work, collection development, reference and instruction, administrative duties," plus logistical tasks required with programming, such as "reserving rooms, posting events to calendars," facilitating assessment, and reporting. Other barriers reported include connecting with the right external partner; oversaturation of campus events; changes within administration; lack of interest; the lack of ability to communicate widely to promote events; and lack of parking, event space, and funds.

\section{Future Directions}

Library strategic planning is leading to new growth in programming by way of departments, staff, and space focused on outreach and collaboration. A few respondents cited positive future directions related to these strategic changes: "Leadership and staff who are committed/ 
interested in outreach and programming; staff dedicated to event logistics and promotion," said one respondent. As libraries undergo renovations, several cited new planned spaces for programming: "We also have a new maker space and recording space opening, which will be a priority for new co-curricular programs," one said. Another shared, "With a newly renovated library, the campus community is eager to use the facility for events, displays, readings." Some described specific plans such as creating a large signature event for each semester or implementing an ongoing series of talks by students, faculty, and visiting researchers. Overall, respondents saw a future for co-curricular programs in their libraries.

\section{Recommendations}

With co-curricular programming, library staff can connect their mission statements to their work, and the programming gives evidence of the libraries' contributions toward larger goals. Interested library staff should be encouraged to develop programs. Administration must compensate staff accordingly through flex time, pay increases, and other measures as necessary.

Mapping to institutional goals can be accomplished with brainstorming and discussion sessions involving stakeholders as indicated in some of the sources in the literature review. Collaborating with potential partners and students will enhance program development and delivery and help determine community needs. Instead of replicating another institution's program, it is effective to draw upon local interests, needs, and assets.

Library workers involved with programming will make a larger impact if they have documents and data to guide their planning and determine their communication channels. A working strategic plan means library workers look to it for guidance, inspiration, and a framework for developing programs. The best strategic plans also offer distinct plans for action that will support the institution in measurable ways. Library administration should share their own reporting strategies with program planners; measurable goals should be set annually. A strategy found during the literature review was offered by Berkeley College, White Plains Campus. LibInsight forms help librarians assess and analyze programming and tracks alignment to institutional goals and to the library's operational goals. ${ }^{29}$ Providing access to reports and sharing results widely using an institutional repository is a great strategy that can be used with administration and program partners. Libraries need to investigate their own localized and effective ways to communicate value, whether it be participation and planning data, or stories that illustrate the impact of co-curricular programs on student learning and engagement.

\section{In Practice}

Upon completion of this study, the author reflected on the results in relation to their library's efforts toward organizing and reporting on co-curricular programming. For many years, the University of Dayton Libraries have presented exhibits, events, and program series. Many factors support these initiatives of public and co-curricular programming: the desire to promote collections; the availability of exhibit and programming space; expertise of library faculty and staff in a team-based environment; positive working relationships with campus units and teaching faculty; and the establishment of a marketing and outreach team. Newly renovated spaces are enhancing the capacity for programming, exhibits, and collaboration. Some of these factors are consistent with the experiences reported by our peers and aspirational peers. 
Results affirmed current practices and provided ideas for development. The university libraries' strategic plan and campus initiatives focused on student programming ${ }^{30}$ and will continue to foster a strong interest in planning events and workshops. A programming steering committee facilitates two open brainstorming sessions to develop ideas prior to each semester. All library staff are encouraged to plan co-curricular programs and exhibits, whether they are in a supporting or leadership role. Group brainstorming sessions will continue, but mentoring practices could further develop.

Reporting is currently accomplished through team and committee reports that are shared and discussed with library administration. The university libraries' co-curricular program quantities and attendance are compiled for our annual report prepared for ACRL. Ideas that were generated from this research include posting final reports to the institutional repository and mapping any assessment or evaluation back to goals and priorities. Stories and experiences from programs could be better captured and shared.

\section{Conclusion}

Studying the connections that libraries make to their institutions' goals and missions helps in examining and analyzing the intended and measured impact of libraries. Survey responses, existing literature, and the Value of Academic Libraries report show a growing commitment by library leadership and staff to co-curricular programming as a valuable form of outreach. Campus partners can share in logistics and recruit new audiences for the library. New spaces and departments are being configured to meet the demand for programming. Survey results and background research provide helpful insights to inform others' work and development in this area. Survey results can be especially informative as the comparable institutions approach program planning and reporting with different strategies but similar goals in mind.

This study used peers and aspirational peers to the University of Dayton as a sample group and, as such, is limited in scope. To expand upon this work, more research on strategic plan implementation and reporting is needed. Additionally, future research could investigate outreach and programming that is happening outside the confines of the library building, including online environments. Research by NILPPA will continue to expand the knowledge base on programming in U.S. libraries overall.

From design and planning to assessment and reporting, programs provide a full package from the library to administration. Leveraging space, collections, and campus expertise and priorities can all help illustrate libraries' value to institutions. Collaboration adds to this demonstration of value by expanding a library's network of partners and champions.

\section{Acknowledgments}

The author would like to thank the survey participants for sharing their experiences; Shannon L. Farrell and Kristen Mastel for permission to use their outreach categories; Heidi Gauder and Patricia Meinking for their input on survey questions; Maureen E. Schlangen and Ione T. Damasco for their feedback and reviews on drafts; editors Jill Becker, Sara Goek, and Wendi Kaspar; and reviewers Mary Francis and Joel Thornton for their guidance. Finally, since the author's sabbatical leave facilitated this project's completion, she extends sincere thanks to colleagues who took on her job responsibilities for the semester: Christina A. Beis, Maureen E. Schlangen, Ione T. Damasco, Zachary Lewis, Jane Dunwoodie, and Janet Peterson. 


\section{APPENDIX. Co-Curricular Programs in Academic Libraries Survey}

Welcome to the survey! This study is investigating how University of Dayton's select peer and aspirational peer group academic libraries facilitate development and communication of co-curricular programs. Upon completion, you will have the opportunity to opt in to receive a $\$ 10$ Amazon credit.

For the purposes of this research, co-curricular programming is defined as programs and series of programs developed proactively by libraries to complement student learning, activities, or interests. "Develop" could mean creating new programs or revamping existing programs.

1. Please select the types of programs your library offers or is currently planning. Categories adapted with permission from: S.L. Farrell and K. Mastel, "Considering Outreach Assessment: Strategies, Sample Scenarios, and a Call to Action," In the Library with the Lead Pipe (2016), available online at www.inthelibrarywiththeleadpipe.org/2016/considering-outreachassessment-strategies-sample-scenarios-and-a-call-to-action/ [accessed 8 July 2019].

- Programs that are designed around your library's collection. Examples may include book clubs, common read events, or exhibits highlighting special collections or archives.

- Co-curricular events that feature presentations or activities on your library's services such as data management or specialized research using databases.

- Programs that are designed to help students make personal progress in some aspect of their life, including health-based programs.

- Programs such as arts and crafts, concerts, puzzles, or games that may positively influence the library environment.

- Programs that cross-promote your library's service with other campus units, showcasing library collections/services at campus or community events outside the library or providing library space for programs led by groups, organizations, or clubs.

- Programs that take place over several days with multiple events and can be a combination of the above categories. May be affiliated with new student orientation, Banned Books Week, Open Access Week, or National Library Week.

2. How often does your library use its own strategic plan, mission, and/or vision to guide its development of co-curricular programs?

Always

$\square$ Very Often

$\square$ Sometimes

$\square$ Rarely

$\square$ Never

3. How does your library's strategic plan influence your library's program development? Please include specific excerpts that inform and guide your planning.

4 . How does your library's mission and vision influence your library's program development? Please include specific excerpts that inform and guide your planning.

5. How often does your library use the institution's mission or learning goals to guide its development of co-curricular programs?

$\square$ Always

$\square$ Very Often

$\square$ Sometimes 
$\square$ Rarely

$\square \quad$ Never

6. How does the institution's mission influence your library's program development? Include specific excerpts that inform and guide your planning.

7. How does the institution's learning goals influence your library's program development? Include specific excerpts that inform and guide your planning.

8. What are other sources of inspiration for your co-curricular program themes or topics? Please check all that apply.

$\square$ Academic Course(s) or Program(s)

$\square$ ACRL Framework for Information Literacy

$\square$ Campus Partners' Expertise or Interest

$\square$ Community Partners' Expertise or Interest

$\square$ Current Events (Local, National, International)

$\square \quad$ The Institution's Special Collections or Archives

$\square$ The Institution's Arts Programming

$\square \quad$ The Institution's Research Focus Areas

$\square$ Faculty Expertise or Interest

$\square$ Library Employee Expertise or Interest

$\square \quad$ Local History

$\square \quad$ National Themed Months or Weeks

$\square \quad$ Other Institutions, including Academic Libraries

$\square \quad$ Public Library Programs

$\square \quad$ Student Expertise or Interest

$\square$ Other:

9. Who plans library programming?

10. Please describe any barriers your library might have experienced with program development.

11. What factors contribute positively to your program development?

12. What are some future directions of your library's programming?

13. Are programming results or outcomes reported to library administration? If so, how?

14. Does the library report programming results or outcomes to the institution's administration? If so, how?

15. Do you have a programming report or other program documentation you are willing to share with the researcher? Please email a PDF to kkelly2@udayton.edu or provide the link(s) here.

16. Is there anything you would like to add about your library's program development?

17. What job area(s) do you currently work in?

$\square$ Library Administration

$\square$ Communication/Marketing

$\square$ Programming/Events/Exhibits

$\square$ Reference/Instruction

$\square$ Archives/Special Collections

18. What is the name of your institution? This information is for peer group comparison only and will remain confidential. 


\section{Notes}

1. Association of College and Research Libraries (ACRL), Academic Library Impact: Improving Practice and Essential Areas to Research, prepared by Lynn Silipigni Connaway, William Harvey, Vanessa Kitzie, and Stephanie Mikitish of OCLC Research (Chicago, IL: ACRL, 2017).

2. ACRL, Academic Library Impact.

3. Amy Wainwright and Chris Davidson, "Academic Libraries and Non-Academic Departments: A Survey and Case Studies on Liaising Outside the Box," Collaborative Librarianship 9, no. 2 (2017): 117-34.

4. Erin E. Meyer, "Low-Hanging Fruit: Leveraging Short-Term Partnerships to Advance Academic Library Outreach Goals," Collaborative Librarianship 6, no. 3 (2014): 112-20.

5. Silas M. Oliveira, "Retention Matters: Academic Libraries Leading the Way," New Review of Academic Librarianship 24, no. 1 (2018): 35-47.

6. Mary O'Kelly, “Community Success: Rethinking Public Services in Academic Libraries," International Information \& Library Review 49, no. 3 (2017): 226-27.

7. Ray Oldenburg, The Great Good Place: Cafés, Coffee Shops, Community Centers, Beauty Parlors, General Stores, Bars, Hangouts, and How They Get You Through the Day (New York, NY: Paragon House, 1989): 42.

8. Kathleen Kasten, "Library as Forum: Building Relationships and Identity through Faculty Speaker Events," New Review of Academic Librarianship 24, no. 3/4 (2018): 406.

9. Kristin Fontichiaro, Library 2020: Today's Leading Visionaries Describe Tomorrow's Library, ed. Joseph Janes (Lanham, MD: Scarecrow Press, 2013): 15.

10. Rosan Mitola, "Plan, Prioritize, and Partner: A Model to Create Successful Outreach Programs and Events," in Successful Campus Outreach for Academic Libraries: Building Community Through Collaboration, eds. Peggy Keeran and Carrie L. Forbes (Lanham, MD: Rowman \& Littlefield, 2018), 3.

11. Mitola, "Plan, Prioritize, and Partner," 9.

12. Shannon L. Farrell and Kristen Mastel, "Considering Outreach Assessment: Strategies, Sample Scenarios, and a Call to Action," In the Library with the Lead Pipe (May 2016), available online at www.inthelibrarywiththeleadpipe.org/2016/considering-outreach-assessment-strategies-sample-scenarios-and-a-call-to-action/ [accessed 8 July 2019].

13. Silipigni Connaway et al., Academic Library Impact, 39.

14. Association of College and Research Libraries (ACRL), The Value of Academic Libraries: A Comprehensive Research Review and Report, prepared by Megan Oakleaf (Chicago, IL: ACRL, 2010).

15. ACRL, The Value of Academic Libraries, 29-30.

16. Bonnie Lafazan and Jessica Kiebler, “Promotion Doesn't End When Your Event Is Over: The Value of Post-Promoting Your Outreach," Public Services Quarterly 13, no. 4 (2017): 291.

17. Mary O'Kelly, “Seven Questions for Assessment Planning: A Discussion Starter. College and Research Libraries News 76, no. 9 (2015): 488-94.

18. Dianne Cmor, "Strategies for Sustainable Services in Academic Libraries," Library Management 6/7 (2016): 300.

19. Sarah McNicol, “The Challenges of Strategic Planning in Academic Libraries," New Library World 11/12 (2005): 505-06.

20. Kaitlin Springmier, Elizabeth Edwards, and Michelle B. Bass, "Sharing Success: A Review of Strategic Planning, Annual Reports, and Publicly Available Information from Academic Libraries," Evidence Based Library E Information Practice 13, no. 2 (2018): 77.

21. ALA, "National Impact of Library Public Programming Assessment (NILPPA) White Paper," (Dec. 2014): 6, available online at https://nilppa.org/wp-content/uploads/2014/NILPPA_White_Paper_FINAL_web.pdf [accessed 8 July 2019].

22. Beverly Sheppard et al., "National Impact of Library Public Programs Assessment: Phase 1, A White Paper on the Dimensions of Library Programs \& the Skills and Training for Library Program Professionals" (Chicago, IL: American Library Association \& New Knowledge Organization Ltd., 2019): 7, available online at https://nilppa.org/ [accessed 15 July 2019].

23. Sarah LeMire et al., Outreach and Engagement, SPEC Kit 361 (Washington, DC: Association of Research Libraries, Nov. 2018), 5.

24. LeMire et al., Outreach and Engagement, SPEC Kit 361, 3.

25. Indiana University Center for Postsecondary Research, The Carnegie Classification of Institutions of Higher Education, "Size \& Setting Classification Description," available online at http://carnegieclassifications.iu.edu/ classification_descriptions/size_setting.php [accessed 1 February 2019]. 
26. Farrell and Mastel, "Considering Outreach Assessment."

27. ACRL, Academic Library Impact, 4.

28. ACRL, Academic Library Impact, 7.

29. Jessica Kiebler, "Collecting Data for Outreach Using LibInsights" (YouTube video, 2:33, Mar. 19, 2019), available online at https://www.youtube.com/watch?v=4vgG4vzugh0 [accessed 8 July 2019].

30. Katy Kelly, "On the PATH: Library Events Support Student Learning Outcomes" (poster presented at the American Library Association Conference, Chicago, IL, June 2017), available online at https://ecommons. udayton.edu/roesch_fac_presentations/41 [accessed 8 July 2019]. 